\title{
Asynchronous learning techniques during the COVID 19 Pandemic
} \author{
Faiz Bin Zafrah ${ }^{5}$ \\ ${ }^{1}$ Management Information System, King Khalid University, Abha, Aseer, Saudi Arabia \\ ${ }^{2}$ Accounting Information System, King Khalid University, Abha, Aseer, Saudi Arabia \\ 3,4 Management Information System, King Khalid University, Abha, Aseer, Saudi Arabia \\ ${ }^{5}$ Business Administration, King Khalid University, Abha, Aseer, Saudi Arabia
}

Osman A. Nasr ${ }^{1,}{ }^{*}$, Abd Almajeed Alajab ${ }^{2}$, Ahmed A. Ahmed ${ }^{3}$, Khalid Mohiuddin ${ }^{4}$,

*Corresponding author Ph: +966562684629 ; oanassr@kku.edu.sa

DOI: https://doi.org/10.34256/irjmt2127

Received: 03-03-2021, Revised: 11-03-2021, Accepted: 15-03-2021, Published: 18-03-2021

Abstract: This study aims to determine the technology-based pedagogies and their learning capabilities that can be used in managing the academic disciplines operational process during the COVID 19 pandemic. It chooses two popular learning management systems, i.e., the Blackboard and Moodle to analyze their capabilities and presents in three folds (i) the abilities of delivering and administrating a course, (ii) students' course performance evaluation, and (iii) the potentiality of evaluating quality evaluation process. The study relies on the exploratory descriptive approach to identify the types of teaching strategies and classify them according to their support for the majors. Further, it investigates for the specific characters that will support laboratory-based courses and the possibilities of quality evaluation. Furthermore, it reveals 28 pedagogy styles from four different academic disciplines, i.e., Arts and Humanities, Medical Education, Science and Engineering, and Social sciences. Finally, the study presents the mechanism of implementing tools of such LMS for achieving the efficiency during learning-teaching process.

Keywords: E learning, Blackboard, Moodle, Teaching Methods, LMS.

\section{Introduction}

Most of the higher education institutions at present aim to provide high-quality education and this aspect is shown by the future vision of the institution, as it prepares students for academic achievement through the acquisition of knowledge and skill, which directly contributes to the growth of countries and the economy [1]. The methods and methods used by academics to communicate knowledge or skill, share it with students, implement them correctly, and customize them according to students' needs, act as a prominent catalyst for students to achieve high academic achievement [2].

It is believed that teachers should demonstrate intent to adapt and customize approaches aimed at improving student learning. The teacher can improve techniques and methods to make the teaching and learning mode more suitable for students. The teacher can also be selective in the use of techniques if he has a worthy knowledge of the available and accessible methods [3]. In every educational discipline, the methods are associated with remarkable teaching and learning outcomes. Here, in this study, some methods from four major disciplines were briefly discussed to show which methods are appropriate and appropriate and their availability in the blackboard e-learning system. The grouping of majors in this regard was flexible according to the nature and knowledge of their academic content [4].

The increase in the number of specializations in the current academic milieu, this constantly changing situation has led to additional challenges for teachers and this requires them to customize and adjust the objectives, context, contents of lessons, and communication patterns between teacher-student, student-teacher, student-student [5]. Teachers' unfamiliarity with teaching methods sometimes complicates the issue of teaching and learning. Some names of additional teaching methods are included in this paper, although they are not widely practiced by academics. At times, these lesser-known methods may be beneficial for innovative teaching techniques [6].

Each major has its requirements and conditions according to the goals that must be achieved. The curriculum makes it possible to implement and achieve these goals through the content of the course, methods of teaching, and the teaching process, and the 
curriculum itself is determined according to its educational objectives concerning the participants and circumstances. In teaching, the approach used is essential for conceptualizing teacher work and student learning. Teaching methods are one of the basic aspects of teaching and learning, which must be specified in any curriculum, which in the first place constitutes a commitment to both teachers and students in implementing what is required of them in the process of delivering the curriculum [7]. The quality of the teaching process sends an implicit message about teaching techniques, student progress in learning, and knowledge acquisition. According to the contemporary development in the teaching and learning environment, the multiplicity of teaching methods and the need for a more balanced use of them is an integral part of the development of each discipline. An understanding of teaching methods greatly influences the quality of teaching, and an understanding and analysis of teaching methods can lead to a deeper understanding of the quality of student learning and teacher work [8].

The study's aims to focus on three objectives: first a characteristics' comparison of learning management systems (LMSs) through the available features. Second, to focus the role of LMSs in e-learning, and third is to propose a model consisting of six independent variables (application, integration, communication, evaluation, and content, Cost, and security) and one dependent variable which are reasons for the success of e-learning. The study's result shows that there is a statistically significant impact of LMS major characteristics on e-learning success [9].

The study provides twelve guiding advices that include a set of basic principles and practical recommendations that can apply to online learning, focusing on design features that can be quickly implemented to face the current epidemic (COVID-19). It also referred to processes for short-term transformations beneficial for long-term integration of educational technology into the infrastructure of institutions [10].

\section{Literature Review}

The presented study aims to solve the problems of LMSs that are mostly related to pedagogical or technology. It introduces a LMS through the conceptual model, based on the combination of four theories of learning (traditional pedagogy, the behaviorism, the cognitivist, and the social constructivism). They will also depend on cooperative education for both the teacher and the learner, with the possibility of creating, managing and proposing different and varied activities. Their interaction with these activities, where and when, according to their needs and learning goals. The study planned to produce a LMS that gives the same working potential to both teachers and learners by distributing their control over the platform [11].

The study also covers the commercial LMSs available and used in the Kingdom of Saudi Arabia through a comparative analysis. The study found that $90 \%$ of universities in the Kingdom of Saudi Arabia use the Blackboard LMS and $7 \%$ of Saudi universities use the Moodle LMS, and 4\% use D2L. All the LMS have the same characteristics of communication and content management for the courses, currently there is no learning management system that provides the features of conducting laboratory experiments [12].

Notably, it discusses assessing the usability of e-learning acceptance models Technology Acceptance Model (TAM), the idea was initially from a review of more recent studies. The results of the review showed usability trends in a specific context. Among the various formulations related to usability that were reached User satisfaction, user interface design, and interaction. The significant effect of the reviewed usability factors was confirmed statistically in most of the studies covered [13].

\section{Purpose of the Study}

The aim of the study to make it easier for teachers to use the most practiced potential teaching methods in four educational disciplines, such as Arts and Humanities (AH), Medical Education (ME), Science and Engineering (SE), and Social Sciences (SS). It provides an analysis of the suitability and availability of each teaching style for the respective discipline in Blackboard e-LMS, as well as a hand-cited analysis of the scientific literature on the teaching methods available on the four major disciplines in higher education. Potential research questions emerge as follows:

Q1: What are the potential teaching methods practiced in higher education?

Q2: What teaching methods are exclusively practiced in the four major disciplines (arts and humanities, medical education, science and engineering, social sciences)?

Q3: How available are the teaching methods involved in the four major disciplines on the Blackboard Learning Management System?

\section{Methodology}

The study relied on the descriptive and analytical approach through which distance education technologies will be described in the educational process in light of the Corona pandemic, as well as analyzing the trends of these technologies, especially those related to the blackboard system and its 
effectiveness in managing the educational process under the conditions of the Corona pandemic [14-15].

\section{Targeted E-learning platforms:}

\subsection{Blackboard Learning Management System}

It is a learning management system that uses a set of tools to create and manage course content, and provide learning resources to students (books, video, audio), and it is one of the systems with a complex structure that serves different aspects of the teaching processes that use different techniques, it is considered a commercial system [16].

The Blackboard Learning Management System (BLMS) is an effective LMS and allows educational institutions to provide electronic courses on the Internet as a supplement to traditional education courses and allows universities to add electronic educational resources for students, such as PowerPoint files, video, audio, movement, and other applications that can be added from the resource. To support curricula, improve teaching and increase learning efficiency.

Remarkably, BLMS allows learners at different levels of e-learning in which they study their courses, a list of the courses available for them to study, information about each course, a list of lectures, and asynchronous communication through the exchange of mail messages and participate in discussion forums between students each other. Or between students and the teacher, providing electronic information sources to support what students are studying, making available a bank of questions related to the course for training, evaluation using performance records, and open and limited discussions [17].

The use of the BLMS requires the learner to master the skills of using the Internet, the skills of using the Internet browser, writing skills, and file management skills and does not need mastery of programming languages or HTML language [16]. And course management systems are an integrated system responsible for managing the electronic educational process through the global network of information "the Internet" that includes admission and registration, course registration, course management, assignments, student learning follow-up, supervision of synchronous and non-synchronous communication tools, examination administration, and final certification [18].

\subsection{Moodle Learning Management System}

It is an open-source learning management system with a multilingual interface, to create an individual, customized, safe and integrated learning environment according to the needs of the educational institution for both the students, teachers and administrators, and it also provides flexible tools to support both blended learning and online learning [19121].

\section{E-learning classifications}

Universities generally offer three levels of Elearning, explained in the table 1 [22]:

Table 1 Explains the similarities and differences between the complete, integrated and supportive elearning levels

\begin{tabular}{|c|c|c|c|}
\hline $\begin{array}{l}\text { The face of } \\
\text { comparison }\end{array}$ & Complete E-Iearning & Blended E-learning & Supportive E-learning \\
\hline $\begin{array}{l}\text { Course Elements: The } \\
\text { course must contain } \\
\text { the following elements } \\
\text { in a learning } \\
\text { management systems: }\end{array}$ & $\begin{array}{l}\text {-The curriculum of the } \\
\text { entire course, including } \\
\text { description, objectives, } \\
\text { assessment and } \\
\text { activities. } \\
\text { - Teacher information. } \\
\text {-Activating the } \\
\text { scheduled bulletin board } \\
\text {-Activating } \\
\text { discussion forum } \\
\text {-Course materials in } \\
\text { references, slides, } \\
\text { presentation, } \\
\text { documents, recordings, } \\
\text { or any other materials or }\end{array}$ & $\begin{array}{l}\text {-The curriculum of the } \\
\text { entire course, including } \\
\text { description, objectives, } \\
\text { assessment and } \\
\text { activities. } \\
\text { - Teacher information. } \\
\text {-Activating the } \\
\text { scheduled bulletin board } \\
\text {-Activating } \\
\text { discussion forum } \\
\text {-Course materials in } \\
\text { references, slides, } \\
\text { presentation, } \\
\text { documents, recordings, } \\
\text { or any other materials or }\end{array}$ & $\begin{array}{l}\text {-The curriculum of the } \\
\text { entire course, including } \\
\text { description, objectives, } \\
\text { assessment and } \\
\text { activities. } \\
\text { - Teacher information. } \\
\text {-Activating the } \\
\text { scheduled bulletin board } \\
\text {-Activating } \\
\text { discussion forum } \\
\text {-Course materials in } \\
\text { references, slides, } \\
\text { presentation, } \\
\text { documents, recordings, } \\
\text { or any other materials or }\end{array}$ \\
\hline
\end{tabular}




\begin{tabular}{|c|c|c|c|}
\hline & $\begin{array}{l}\text { tools that support } \\
\text { learning. } \\
\text { - Activate the basic } \\
\text { virtual classroom }\end{array}$ & $\begin{array}{l}\text { tools that support } \\
\text { learning. } \\
\text { - Activate the basic } \\
\text { virtual classroom }\end{array}$ & $\begin{array}{l}\text { tools that support } \\
\text { learning. } \\
\text {-Activate the virtual } \\
\text { classroom as desired by } \\
\text { the teacher }\end{array}$ \\
\hline Preliminary actions & $\begin{array}{l}\text { A simultaneous } \\
\text { meeting is held between } \\
\text { the students and the } \\
\text { teacher, during which he } \\
\text { clarifies the course plan } \\
\text { and how to proceed with } \\
\text { it }\end{array}$ & $\begin{array}{l}\text { - Determining electronic } \\
\text { attendance dates by } \\
\text { agreement between the } \\
\text { teacher and the students } \\
\text { of the course, provided } \\
\text { that they do not violate } \\
\text { the rules governing } \\
\text { electronic attendance }\end{array}$ & $\begin{array}{l}\text {-The course site in LMS } \\
\text { will be a center for } \\
\text { communication and } \\
\text { activities such as use of } \\
\text { the site, accompanying } \\
\text { tools, announcements } \\
\text { and duties }\end{array}$ \\
\hline Previous requirements & $\begin{array}{l}\text { The first two weeks of } \\
\text { the semester start are } \\
\text { devoted to ensuring } \\
\text { students' basic skills } \\
\text { needed to ensure the } \\
\text { smooth running of the } \\
\text { course, such as using } \\
\text { various course tools and } \\
\text { communicating with a } \\
\text { faculty member. }\end{array}$ & $\begin{array}{l}\text { The percentage of the } \\
\text { part devoted to e- } \\
\text { learning from the actual } \\
\text { teaching hours is } \\
\text { determined at three } \\
\text { levels: } 25 \%, 50 \% \text { and } \\
75 \% \text {, and the agreed } \\
\text { and approved } \\
\text { percentage in the } \\
\text { integrated course } \\
\text { teaching application } \\
\text { form must be adhered } \\
\text { to. }\end{array}$ & $\begin{array}{l}\text { Electronic materials in } \\
\text { support of the course are } \\
\text { made available on the } \\
\text { site respectively, such } \\
\text { as Power point slides, } \\
\text { PDF files, or Word files, } \\
\text { followed by the } \\
\text { submission of } \\
\text { assignments and the } \\
\text { activation of the } \\
\text { discussion forum, and } \\
\text { the materials and grades } \\
\text { are delivered and } \\
\text { everything that can be } \\
\text { done during the site }\end{array}$ \\
\hline Course & $\begin{array}{l}\text { Scores for electronic } \\
\text { activities are calculated } \\
40 \% \text { of the e-course }\end{array}$ & $\begin{array}{l}\text { Scores for electronic } \\
\text { activities are calculated } \\
25 \% \text { of the total course } \\
\text { score }\end{array}$ & $\begin{array}{l}15 \% \text { of the total course } \\
\text { score is devoted to } \\
\text { electronic activities }\end{array}$ \\
\hline $\begin{array}{l}\text { Dates of adding } \\
\text { activities on the site }\end{array}$ & $\begin{array}{l}\text { The teacher is obligated } \\
\text { to add two electronic } \\
\text { activities in the course } \\
\text { per week with } \\
\text { determining the timing of } \\
\text { the end of each activity } \\
\text { separately, which calls } \\
\text { for the student to enter to } \\
\text { respond to the } \\
\text { participation }\end{array}$ & $\begin{array}{l}\text { The teacher is obligated } \\
\text { to add electronic } \\
\text { activities to the course at } \\
\text { least once a week, which } \\
\text { requires the student to } \\
\text { enter to respond and } \\
\text { participate. }\end{array}$ & $\begin{array}{l}\text { The teacher is free to } \\
\text { add activities, in } \\
\text { agreement with } \\
\text { students, and report } \\
\text { activities on the course } \\
\text { bulletin board. }\end{array}$ \\
\hline
\end{tabular}

\section{Results and Discussion}

Teaching Methods in Higher Education these paper shows are available Teaching Methods being practiced in the disciplines in higher education. Also, it identifies that there is no such study that fully acknowledges similar kinds of work in listing TMs that teachers should adopt. Table 2 and figure 1 organizes the potential TMs in higher education. [23-24]

Teaching methods across disciplines. 28 methods were drawn that can be used in different scientific disciplines. These are methods that are not used exclusively in a particular discipline. It can be adapted to a variety of conditions. E-learning, lectures, and problem-based learning are found in all four disciplines. In addition, 10 of the methods were applied in three disciplines in different groups. Table 3 lists the teaching methods that were used across the different practical disciplines [25-26]. 
Table 2 Clarifies teaching methods classified according to scientific specializations [24]

\begin{tabular}{|c|c|c|c|}
\hline $\begin{array}{l}\text { Arts and Hun } \\
\text { (AH) }\end{array}$ & $\begin{array}{r}\text { Medical Edu } \\
\text { (ME) }\end{array}$ & $\begin{array}{l}\text { ce and } \\
\text { ring (SE) }\end{array}$ & Social Sciences (SS) \\
\hline $\begin{array}{l}\text { Artists' talks } \\
\text { Communicative } \\
\text { Language teaching } \\
\text { Consultancy } \\
\text { Data-driven learning } \\
\text { Desuggestopedia } \\
\text { Discovery method } \\
\text { Event-based learning } \\
\text { Grammar-translation } \\
\text { method } \\
\text { Live projects } \\
\text { Multiple intelligence } \\
\text { Peer learning } \\
\text { Simulating conditions of } \\
\text { industry } \\
\text { Task-teach-task } \\
\text { Total physical response }\end{array}$ & $\begin{array}{l}\text { CAL and tape/slide } \\
\text { Clinical case } \\
\text { Didactic teaching } \\
\text { Dissection by students } \\
\text { Experiments } \\
\text { Hybrid group } \\
\text { Hybrid tutorial } \\
\text { Living and radiological } \\
\text { Models } \\
\text { Online-only group } \\
\text { Prosection and demo } \\
\text { Self-study sessions } \\
\text { Serious games } \\
\text { Structured lectures } \\
\text { Tape-slide program } \\
\text { Teaching with real } \\
\text { patients } \\
\text { Theoretical-practical } \\
\text { Seminars } \\
\text { Tuition } \\
\text { Use of animal models } \\
\text { Video + handout } \\
\text { VTS teaching method }\end{array}$ & $\begin{array}{l}\text { Activity } \\
\text { Blog } \\
\text { Both activity and lecture } \\
\text { Dialogic } \\
\text { Extended analogy } \\
\text { Face-to-face } \\
\text { Group work } \\
\text { Homework } \\
\text { In-class discussion } \\
\text { Invited expert lecture } \\
\text { Jigsaw } \\
\text { Lecture handouts } \\
\text { Lecture } \\
\text { collaborative } \\
\text { exercises } \\
\text { Lecture with PowerPoint } \\
\text { Low-tech hands-on } \\
\text { Making/reading peer } \\
\text { reviews } \\
\text { Perceptional teaching } \\
\text { S-lecture } \\
\text { Simulated international } \\
\text { conference } \\
\text { Video and micro-lecture } \\
\text { Virtual internship } \\
\text { Web-based laboratories }\end{array}$ & $\begin{array}{l}\text { Applied projects } \\
\text { Behavioral simulation } \\
\text { Business plan creation } \\
\text { Development of new } \\
\text { venture creation project } \\
\text { Discussion and debates } \\
\text { Expert script } \\
\text { Group presentation } \\
\text { Guest speaker } \\
\text { In-class exercises } \\
\text { Individual presentation } \\
\text { Individual } \\
\text { Interview project } \\
\text { Journal article } \\
\text { Lecture/discussion } \\
\text { combination } \\
\text { Library exercise } \\
\text { Life stories } \\
\text { Management simulation } \\
\text { Mind mapping } \\
\text { Real-life case } \\
\text { Role model } \\
\text { Self-analysis } \\
\text { Teaching through the } \\
\text { classics } \\
\text { Virtual } \\
\text { Virtual } \\
\text { program simulation }\end{array}$ \\
\hline
\end{tabular}

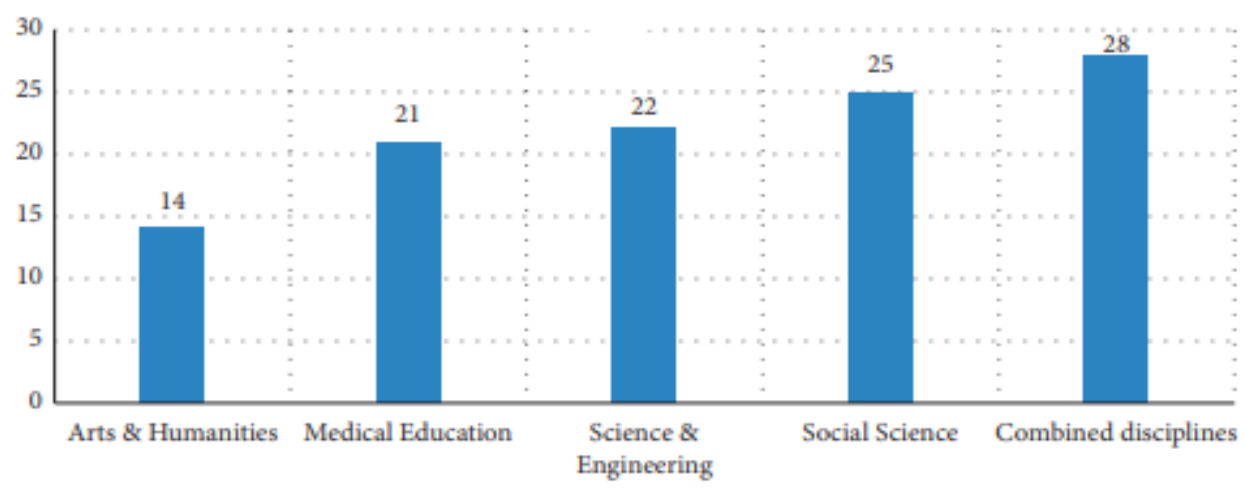

Figure 1 Number of significant TMs in each discipline 
Table 3 A matrix illustrating the teaching strategy and the preferred fields for use in it

\begin{tabular}{|c|c|c|}
\hline $\mathbf{S}$ & Teaching methods & Educational disciplines \\
\hline 1 & Brainstorming & $\mathrm{AH}, \mathrm{ME}, \mathrm{SS}$ \\
\hline 2 & Business/computer/game simulations & $\mathrm{AH}, \mathrm{ME}, \mathrm{SS}$ \\
\hline 3 & Case-based teaching method & SE, SS \\
\hline 4 & Cooperative learning group & $\mathrm{AH}, \mathrm{SS}$ \\
\hline 5 & Demonstration & $\mathrm{AH}, \mathrm{SE}$ \\
\hline 6 & Discussion sessions & $\mathrm{AH}, \mathrm{ME}, \mathrm{SS}$ \\
\hline 7 & E-learning/web-based learning & $\mathrm{AH}, \mathrm{ME}, \mathrm{SE}, \mathrm{SS}$ \\
\hline 8 & Flipped classroom & $\mathrm{AH}, \mathrm{ME}, \mathrm{SE}$ \\
\hline 9 & Game-based learning & SE, SS \\
\hline 10 & Group discussion & $\mathrm{AH}, \mathrm{SS}$ \\
\hline 11 & Handout & ME, SS \\
\hline 12 & Individual written report & SE, SS \\
\hline 13 & Industrial training & SE, SS \\
\hline 14 & Inquiry-based learning & $\mathrm{AH}, \mathrm{SE}, \mathrm{SS}$ \\
\hline 15 & Keller method & ME, SE \\
\hline 16 & Lab work & ME, SS \\
\hline 17 & Lecture & $\mathrm{AH}, \mathrm{ME}, \mathrm{SE}, \mathrm{SS}$ \\
\hline 18 & Practical sessions & ME, SE \\
\hline 19 & Problem-solving & $\mathrm{AH}, \mathrm{ME}, \mathrm{SS}$ \\
\hline 20 & Problem-based learning & $\mathrm{AH}, \mathrm{ME}, \mathrm{SE}, \mathrm{SS}$ \\
\hline 21 & Project-based learning/group project & $\mathrm{AH}, \mathrm{SE}, \mathrm{SS}$ \\
\hline 22 & Research-oriented teaching & SE, SS \\
\hline 23 & Role playing & $\mathrm{AH}, \mathrm{SS}$ \\
\hline 24 & Seminar/workshop & $\mathrm{AH}, \mathrm{SS}$ \\
\hline 25 & Small group & ME, SE, SS \\
\hline 26 & Team-based learning & $\mathrm{AH}, \mathrm{ME}, \mathrm{SS}$ \\
\hline 27 & Video/video recorded lecture & ME, SE, SS \\
\hline 28 & Work-based learning & $\mathrm{AH}, \mathrm{SE}$ \\
\hline
\end{tabular}

Table 4 Mechanisms for implementing teaching methods in the four major disciplines on learning management systems (Blackboard and Moodle)

\begin{tabular}{|l|l|l|l|l|}
\hline S & \multicolumn{1}{|c|}{ Teaching methods } & \multicolumn{1}{|c|}{$\begin{array}{c}\text { Educational } \\
\text { disciplines }\end{array}$} & $\begin{array}{c}\text { Execution mechanism via } \\
\text { Blackboard }\end{array}$ & $\begin{array}{l}\text { Execution } \\
\text { mechanism via } \\
\text { Moodle }\end{array}$ \\
\hline 1 & Brainstorming & AH, ME, SS & $\begin{array}{l}\text { Forums, and virtual } \\
\text { interactive classes }\end{array}$ & $\begin{array}{l}\text { Forums, and } \\
\text { virtual interactive } \\
\text { classes }\end{array}$ \\
\hline
\end{tabular}


Osman A. Nasr et al., /2021

\begin{tabular}{|c|c|c|c|c|}
\hline 2 & $\begin{array}{l}\text { Business/computer/game } \\
\text { simulations }\end{array}$ & $\mathrm{AH}, \mathrm{ME}, \mathrm{SS}$ & $\begin{array}{lcc}\text { Forums, and } & \text { virtual } \\
\text { interactive classes } & \end{array}$ & $\begin{array}{l}\text { Forums, and } \\
\text { virtual interactive } \\
\text { classes }\end{array}$ \\
\hline 3 & $\begin{array}{l}\text { Case-based teaching } \\
\text { method }\end{array}$ & SE, SS & $\begin{array}{l}\text { Forums, virtual interactive } \\
\text { classes, WIKI }\end{array}$ & $\begin{array}{l}\text { Forums, virtual } \\
\text { interactive } \\
\text { classes }\end{array}$ \\
\hline 4 & $\begin{array}{ll}\text { Cooperative } & \text { learning } \\
\text { group } & \end{array}$ & $\mathrm{AH}, \mathrm{SS}$ & $\begin{array}{l}\text { Forums, and virtual } \\
\text { interactive classes }\end{array}$ & $\begin{array}{l}\text { Forums, and } \\
\text { virtual interactive } \\
\text { classes }\end{array}$ \\
\hline 5 & Demonstration & $\mathrm{AH}, \mathrm{SE}$ & virtual interactive classes & $\begin{array}{l}\text { virtual interactive } \\
\text { classes }\end{array}$ \\
\hline 6 & Discussion sessions & $\mathrm{AH}, \mathrm{ME}, \mathrm{SS}$ & virtual interactive classes & $\begin{array}{l}\text { virtual interactive } \\
\text { classes }\end{array}$ \\
\hline 7 & $\begin{array}{l}\text { E-learning/web-based } \\
\text { learning }\end{array}$ & $\mathrm{AH}, \mathrm{ME}, \mathrm{SE}, \mathrm{SS}$ & $\begin{array}{l}\text { Interactive classes, forums, } \\
\text { virtual interactive classes, } \\
\text { WIKI sites }\end{array}$ & $\begin{array}{l}\text { Interactive } \\
\text { classes, forums, } \\
\text { virtual interactive } \\
\text { classes }\end{array}$ \\
\hline 8 & Flipped classroom & $\mathrm{AH}, \mathrm{ME}, \mathrm{SE}$ & virtual interactive classes & $\begin{array}{l}\text { virtual interactive } \\
\text { classes }\end{array}$ \\
\hline 9 & Game-based learning & SE, SS & virtual interactive classes & $\begin{array}{l}\text { virtual interactive } \\
\text { classes }\end{array}$ \\
\hline 10 & Group discussion & $\mathrm{AH}, \mathrm{SS}$ & $\begin{array}{l}\text { Groups, forums, and virtual } \\
\text { interactive classes }\end{array}$ & $\begin{array}{l}\text { forums, and } \\
\text { virtual interactive } \\
\text { classes }\end{array}$ \\
\hline 11 & Handout & ME, SS & $\begin{array}{l}\text { Diaries, file uploads, forums, } \\
\text { and virtual interactive classes }\end{array}$ & $\begin{array}{l}\text { file uploads, } \\
\text { forums, } \quad \text { and } \\
\text { virtual interactive } \\
\text { classes }\end{array}$ \\
\hline 12 & Individual written report & SE, SS & $\begin{array}{l}\text { Diaries, file uploads, forums, } \\
\text { and virtual interactive classes }\end{array}$ & $\begin{array}{l}\text { file uploads, } \\
\text { forums, } \quad \text { and } \\
\text { virtual interactive } \\
\text { classes }\end{array}$ \\
\hline 13 & Industrial training & SE, SS & virtual interactive classes & $\begin{array}{l}\text { virtual interactive } \\
\text { classes }\end{array}$ \\
\hline 14 & Inquiry-based learning & $\mathrm{AH}, \mathrm{SE}, \mathrm{SS}$ & $\begin{array}{l}\text { Forums, and virtual } \\
\text { interactive classes }\end{array}$ & $\begin{array}{l}\text { Forums, and } \\
\text { virtual interactive } \\
\text { classes }\end{array}$ \\
\hline 15 & Keller method & ME, SE & -- & -- \\
\hline 16 & Lab work & ME, SS & virtual interactive classes & $\begin{array}{l}\text { virtual interactive } \\
\text { classes }\end{array}$ \\
\hline 17 & Lecture & $\mathrm{AH}, \mathrm{ME}, \mathrm{SE}, \mathrm{SS}$ & virtual interactive classes & $\begin{array}{l}\text { virtual interactive } \\
\text { classes }\end{array}$ \\
\hline 18 & Practical sessions & ME, SE & virtual interactive classes & $\begin{array}{l}\text { virtual interactive } \\
\text { classes }\end{array}$ \\
\hline 19 & Problem-solving & $\mathrm{AH}, \mathrm{ME}, \mathrm{SS}$ & Forums, discussion boards & $\begin{array}{l}\text { Forums, } \\
\text { discussion boards }\end{array}$ \\
\hline 20 & Problem-based learning & $\mathrm{AH}, \mathrm{ME}, \mathrm{SE}, \mathrm{SS}$ & Forums, discussion boards & $\begin{array}{l}\text { Forums, } \\
\text { discussion boards }\end{array}$ \\
\hline
\end{tabular}




\begin{tabular}{|l|l|l|l|l|}
\hline 21 & $\begin{array}{l}\text { Project-based } \\
\text { learning/group project }\end{array}$ & AH, SE, SS & Forums, discussion boards & $\begin{array}{l}\text { Forums, } \\
\text { discussion boards }\end{array}$ \\
\hline 22 & $\begin{array}{l}\text { Research-oriented } \\
\text { teaching }\end{array}$ & SE, SS & $\begin{array}{l}\text { Discussion boards, blogs, } \\
\text { WIKI sites }\end{array}$ & $\begin{array}{l}\text { Discussion } \\
\text { boards }\end{array}$ \\
\hline 23 & Role playing & AH, SS & virtual interactive classes & $\begin{array}{l}\text { virtual interactive } \\
\text { classes }\end{array}$ \\
\hline 24 & Seminar/workshop & AH, SS & virtual interactive classes & $\begin{array}{l}\text { virtual interactive } \\
\text { classes }\end{array}$ \\
\hline 25 & Small group recorded & ME, SE, SS & Registered classes & $\begin{array}{l}\text { Registered } \\
\text { classes }\end{array}$ \\
\hline 26 & Team-based learning & AH, ME, SS & Groups, forums \\
\hline 27 & $\begin{array}{l}\text { Video/video } \\
\text { lecture }\end{array}$ & AH, SE & $\begin{array}{l}\text { Discussion boards, blogs, } \\
\text { WIKI sites }\end{array}$ & $\begin{array}{l}\text { Discussion } \\
\text { boards }\end{array}$ \\
\hline 28 & Work-based learning & \multicolumn{2}{|l}{} \\
\hline
\end{tabular}

Table 5 The difference between Blackboard and Moodle

\begin{tabular}{|l|l|}
\hline \multicolumn{1}{|c|}{ Blackboard } & \multicolumn{1}{|c|}{ Moodle } \\
\hline $\begin{array}{l}\text { Closed source system - commercial (a sum of money is } \\
\text { paid plus the cost of use according to the number of } \\
\text { courses offered and the number of learners enrolled in it) }\end{array}$ & It is an open source, not-for-profit system \\
\hline Ease of use for teachers and learners & Ease of use for teachers and learners \\
\hline $\begin{array}{l}\text { There is more than one way to communicate with the } \\
\text { registered learners }\end{array}$ & $\begin{array}{l}\text { There is more than one way to communicate with the } \\
\text { registered learners }\end{array}$ \\
\hline Available in more than one language & Available in 75 programming languages \\
\hline Display educational content in more than one way & Display electronic courses in more than one format \\
\hline The degree of safety and technical support is high & The degree of safety and technical support is high. \\
\hline $\begin{array}{l}\text { The cost of using the system depends on the number of } \\
\text { learners registered in the system }\end{array}$ & Scalable by other developers \\
\hline
\end{tabular}

Through the previous discussions, a comparison was made between e-learning management systems (Blackboard and Moodle) depending on the teaching methods available for each system that can be used in the educational process. The comparison was explained through Table 4 and 5.

\section{Conclusion}

The study reviewed distance education techniques in light of the Corona pandemic (Covid 19), and showed that there are 28 teaching methods that can be used in the four scientific disciplines: arts and humanities, medical sciences, science and engineering, and social sciences, and the study showed that there are three levels of e-learning: education Full e-learning, integrated e-learning and supportive e-learning and showed the similarities and differences between the three levels of e-learning, and explained that there is a great similarity between full e-learning and integrated e- learning, but they differ from supportive e-learning, as the study showed that complete e-learning is more used and comprehensive in Teaching procedures.

The study also indicated that the teaching methods used in the social sciences, science and engineering amounted to 22 teaching styles out of a total of 28 teaching styles, with a rate of $78.5 \%$, while in medical education 19, 19 teaching methods were used, representing $67.8 \%$ of the total of 28 teaching styles, while the methods The teaching methods used in the arts and human sciences amounted to 14 teaching styles, accounting for $50 \%$ of the total teaching methods. The teaching methods varied between brainstorming, simulations, case studies, seminars, cooperative education, and others, with the aim of developing students' scientific, creative and innovative skills. The implementation mechanism through the Blackboard was distributed among forums, interactive virtual classes, discussion boards, groups, recorded classes, blogs and wikis, but it was found that the interactive virtual 
classrooms are the most used and interactive in the processes of teaching methods via the Blackboard or Moodle.

\section{References}

[1] Samreen Mahmood, Instructional Strategies for Online Teaching in COVID-19 Pandemic, Human Behavior with Emerging Technologies, 3 (2021 199-203, DOI: https://doi.org/10.1002/hbe2.218

[2] Bijen Filiz, Ferman Konukman, Teaching Strategies for Physical Education during the COVID-19 Pandemic, Journal of Physical Education, Recreation and Dance, 91 (2020) 48-50.

DOI: https://doi.org/10.1080/07303084.2020.181609 $\underline{9}$

[3] Lokanath Mishra, Tushar Gupta, Abha Shree, Online teaching-learning in higher education during lockdown period of COVID-19 pandemic, International Journal of Educational Research Open, $\quad 1 \quad$ (2020) 100012, https://doi.org/10.1016/i.ijedro.2020.100012

[4] S. Bubb, M. A. Jones, Learning from the COVID19 home-schooling experience: Listening to pupils, parents/carers and teachers, Improving Schools, 23 (2020) 209-222. DOI: https://doi.org/10.1177/1365480220958797

[5] R. Olum, L. Atulinda, E. Kigozi, Medical Education and E-Learning During COVID-19 Pandemic: Awareness, Attitudes, Preferences, and Barriers Among Undergraduate Medicine and Nursing Students at Makerere University, Uganda. Journal of Medical Education and Curricular Development. 7 (2020) 1-9. DOI: https://doi.org/10.1177/2382120520973212

[6] C.B. Mpungose, Emergent transition from faceto-face to online learning in a South African University in the context of the Coronavirus pandemic. Humanities and Social Sciences Communications. $7 \quad$ (2020) 113. https://doi.org/10.1057/s41599-020-00603-X

[7] K. Mukhtar, K. Javed, M. Arooj, A. Sethi, Advantages, Limitations and Recommendations for online learning during COVID-19 pandemic era, Pakistan Journal of Medical Sciences, 36(2020).

https://doi.org/10.12669/pjms.36.COVID19S4.2785

[8] Sawsan Abuhammad, Barriers to distance learning during the COVID-19 outbreak: A qualitative review from parents' perspective, Heliyon, 6 (2020) E05482, https://doi.org/10.1016/i.heliyon.2020.e05482

[9] Mohammad Shkoukani, Explore the Major Characteristics of Learning Management Systems and their Impact on e-Learning Success, International Journal of Advanced
Computer Science and Applications ,10 (2019) 296-301.

http://dx.doi.org/10.14569/IJACSA.2019.01001 39

[10] J. Sandars, R. Correia, M. Dankbaar, P. de Jong, Poh Sun Goh, Inga Hege, Ken Masters, So-Young Oh, Rakesh Patel, Kalyani Premkumar, Alexandra Webb, Martin Pusic, Twelve tips for rapidly migrating to online learning during the COVID-19 pandemic, MedEdPublish, 9 (2020) 82, https://doi.org/10.15694/mep.2020.000082.1

[11] M. Ouadoud, M.Y. Chkouri, A. Nejjari, Learning Management System and the Underlying Learning Theories: Towards a new Modeling of an LMS, International Journal of Information Technology, 2 (2018) 25-33, ISSN 2550-5114.

[12] Abdulaziz Aldiab, Harun Chowdhury, Alex Kootsookos, Firoz Alam, Hamed Allhibi, Utilization of Learning Management Systems (LMSs) in higher education system: A case review for Saudi Arabia, Energy Procedia, 160 (2019) 731-737, ISSN 1876-6102, https://doi.org/10.1016/j.egypro.2019.02.186

[13] S. Poelmans, P. Wessa, K. Milis, E. Bloemen, C. Doom, Usability and acceptance of e-learning in statistics education, based on the compendium platform, International Association of Technology, Education and Development, Madrid, ICERI 2008: Researching Learning in Virtual Environments, Date: 2008/11/17 2008/11/19, Location: Madrid, Spain, Proceedings of the international conference of education, research and innovation, Available at:

https://www.wessa.net/download/iceripaper1.p df.

[14] C.R. Kothari, (2004) Research Methodology: Methods and Techniques, New Age International Publishers, New Delhi, India.

[15] S. Loeb, S. Dynarski, D. McFarland, P. Morris, S. Reardon, S. Reber, Descriptive Analysis in Education: A Guide for Researchers. NCEE 2017-4023, National Center for Education Evaluation and Regional Assistance, March 2017.

[16] R.Coetzee, (n.d.). Getting to know the blackboard learning system. Retrieved January 12, 2014 from: www.ufh.ac.za/tlc/sites/

[17] S. Binyamin, M. Rutter, S. Smith, (2017) The Students' Acceptance of Learn-ing Management Systems in Saudi Arabia: A Case Study of King Abdulaziz Uni-versity, International Academy of Technology, Education and Development (IATED), Valencia, Spain. https://doi.org/10.21125/inted.2017.2205

[18] U. T. Alturki, A. Aldraiweesh, Kinshuck, Evaluating the Usability and Accessibility of LMS" Blackboard" at King Saud University, 
Contemporary Issues in Education Research, 9 (2016) https://doi.org/10.19030/cier.v9i1.9548

[19] C.B. Mpungose, Is Moodle or WhatsApp the preferred e-learning platform at a South African university? First-year students' experiences. Education and Information Technologies. 25 (2020) $927-$ 941.https://doi.org/10.1007/s10639-01910005$\underline{5}$

[20] M. Zabolotniaia, Z. Cheng, E. Dorozhkin, A. Lyzhin,. Use of the LMS Moodle for an Effective Implementation of an Innovative Policy in Higher Educational Institutions. International Journal of Emerging Technologies in Learning (iJET), 15 (2020) 172-189. Kassel, Germany: International Journal of Emerging Technology in Learning. Retrieved March 2, 2021 from https://www.learntechlib.org/p/217602/

[21] A. Alghafis, A. Alrasheed, A. Abdulghany, (2020) A Study on the Usability of Moodle and Blackboard - Saudi Students Perspectives. International Association of Online Engineering. Retrieved. March 3, 2021 from https://www.learntechlib.org/p/217784/

[22] J. Wongwuttiwat, V. Buraphadeja, T. Tantontrakul, A case study of blended elearning in Thailand, Interactive Technology and Smart Education, 17 (2020) 197-214. https://doi.org/10.1108/ITSE-10-2019-0068

[23] D. Adom, S. Adam, O. Agyemang, Effective instructional methods and strategies for teaching art history, International Journal of Art and Art History, 4 (2016) 45-62.

[24] M.-A. Sim, A.-M. Pop, Mind mapping and brainstorming as methods of teaching business concepts in English as a foreign language, Academic Science Journal, Psychological Series, 1 (2012) 75-83.

[25] Khalid Mohiuddin, Mohammad Aminul Islam, Mansoor Sharif, Shakila Nur, Md. Shahrear Talukder, Mohammed A Alghobiri, Enumeration of Potential Teaching Methods in Higher Education: $\quad$ A $\quad$ Cross-Disciplinary Study, Education Research International, 2020 (2020)

17. https://doi.org/10.1155/2020/8870412

[26] K. Mohiuddin, M. Islam, S. Talukder, M. Alghobırı, M. Miladi, A. Ahmed, Integrating Assessment and Performance Measurement: A Case of an Academic Course for Quality Improvement Actions at a Saudi University. International Journal of Assessment Tools in Education, 7 (2020) 436-450. DOI: 10.21449 /ijate.636370
Acknowledgement

The authors extend their appreciation to the Deanship of Scientific Research at King Khalid University for funding this work through General Research Project under grant number (58/2021).

\section{Conflict of interest}

The authors have no conflicts of interest to declare that they are relevant to the content of this article.

\section{Does the Article Screened for Similarity?}

Yes.

\section{Author's contribution}

Both the authors equally contributed to this work.

About the License

(C) The author(s) 2021. The text of this article is open access and licensed under a Creative Commons Attribution 4.0 International License

\section{Cite this Article}

Osman A.Nasr, Abd Almajeed Alajab, Ahmed A. Ahmed, Khalid Mohiuddin, Faiz Bin Zafrah, Asynchronous learning techniques during the COVID 19 Pandemic, International Research Journal of Multidisciplinary Technovation, 3(2) (2021) 39-48.

DOI: 